\title{
THE MEANING OF THE KNIGHT RANK OF IVAN GONTA IN "HAYDAMAKS" BY TARAS SHEVCHENKO: HERMENEUTICAL-COMPARATIVE ASPECT
}

\section{Ivanyshyn P. V.}

\section{INTRODUCTION}

Like all the great works of genius authors, the poem "Haydamaks" by Taras Shevchenko constantly attracts the attention of both the specialists and the average reader. Its large-scale, vivid, impressive images left no one from generations of Ukrainians indifferent. Another specificity of the reception of this unique work is variegated, up to the diametrical opposites, interpretative valuations. In general, these valuations can be taken down to three main types (of course, with numerous modifications and subtypes): 1) mostly negative, in which the poem is examined as weakly aesthetically and ideologically, as the work of "not the best", "non-European" (M. Drahomanov, P. Kulish, the young I. Franko, M. Rudnytsky, and others); 2) mostly apologetic, as an artistic value work (O. Ogonovskiy, S. Smal-Stotskiy, L. Biletskiy, D. Dontsov, E. Malanyuk, I. Bryck, Yu. Boyko, V. Smilyanska, G. Klochek, N. Zborovska, Val. Shevchuk, M. Naenko, I. Dzyuba, etc.) and 3) dualistic as a work obviously or hidden ambivalent and contradictory in the ideological and aesthetic plans (partly V. Paharenko, fully Ye. Nahlik, Yu. Barabash and others). For each of these positions there are its logic, methodology, ideology, arguments. However, they are not always checked by the intentions of the work itself, and sometimes simply imposed to the recipient as if it were Shevchenko's auto- valuations.

A typical example of the most controversial interpretation can be the image of one of the protagonists - the leader of the Haydamak's uprising Ivan Gonta. Especially, the culminating episode of the work is the scene of the murder of sons in the part "Gonta in Uman". This impressive rank rarely received deeper interpretation (as in L. Biletskiy or Val. Shevchuk), more often it was only fixed as "the most tragic" scene or "terrible act" 
without a deeper analysis (for example, in I. Bryck or I. Dzyuba) or tendentiously over-interpreted (in the terminology of U. Eko), made it the main proof of the "immorality" and "antiheroicity" of the poem in general (G. Grabovych) and "criminality", "demonicity", "ghoulsness" of the centurion (and, in the same way, all the haydamaks) specifically (L. Plyushch, O. Zabuzhko, G. Grabovych). Even some more thoughtful researchers were inclined to consider Gonta as a victim of the "demons" of "confessional intolerance" and "swarm's solidarity", and his rank - as an act of "moral fall"1.

The problem of full-fledged interpretation of the Gonta's action, which is one of the main keys to the interpretation of the poem in general, needs much more space and time (for example, an appeal to the interpretation of the Koliyivshchyna as a complex historical phenomenon, to ethnopsychological conception of "two Ruthenian nationalities" by M.Kostomarov, to a religious basis of the liberation wars, to the problem of the methodological (not) adequacy of the various interpretations of the work, etc.). Here we confine ourselves to the semantic, hermeneutic outlining of only one comparative aspect which has not yet become the subject of in-depth examination and which, in our opinion, spills some light on the essence of this drastic scene for many researchers, on the temper of the Haydamak leader, and on the deeper meanings of the whole poem.

\section{Gonta as a personification of knightly (extraordinary) type of presence in T. Shevchenko}

Since we are going to talk about parallels with the ancient authorshistorians, then it is also appropriate to point out some (obviously partial) intermediality of the carried out comparative interpretation. In the professional literature the thought, that the antique historiography (Homer, Thucydides, Caesar, Sallust, Titus Livius, Plutarch, Polybius, Tacitus, etc.) was a genre of not so much science as literature, more concretely as artistic prose, became normative. From here - the richness of historical texts with vivid and lively artistic descriptions, the dramatization of the narration, the

\footnotetext{
${ }^{1}$ Барабаш Ю. “Коли забуду тебе, Срусалиме...”. Гоголь і Шевченко. Порівняльнотипологічні студії. Харків. Акта. 2001. С. 169.
} 
containing of invented speeches and letters, the domination of artistic truth over the truth of the fact, etc. ${ }^{2}$ There is some reason to consider these genre synthetic works as close to documentary literature, that is to "artistic and journalistic, scientific and artistic works.., based on the full or partial use of documentary sources"3. Thus, in our case, it is a question of comparing T. Shevchenko's poem as a purely artistic work with the typical works of ancient historians (as syncretic semiotic systems). (Instead, the classical example of a thorough intermedial interpretation of the creative work of T. Shevchenko is the recent works of Gregory Klochek or the monograph of Lesya Generalyuk ${ }^{4}$ ).

The purpose of such a fragmentary hermeneutic-comparative reading is to find out the typical semantic aspects of Ivan Gonta's action in the poem "Haydamaks" through comparison with typologically close inocultural experience, as well as generalization of previous developments ${ }^{5}$.

First of all, if we approach the literary figure of Gonta with impartiality and taking into account that we deal with one of the through archetypal images in the poetry of T. Shevchenko ("To Gogol", "Cold Ravine", "The Great Cellar"), then it is obvious that this character has an in-depth meaning for the poet's creative work. And it is not just that Shevchenko, in the spirit of romantic, "Cossack" (according to Ivan Franko) nationalism, in his creative work models a new type of Ukrainian national man, as a person of a specific free man, a Cossack man. It is also important to realize the other. Within this free Cossack life, he distinguishes ordinary and conducting types. The orphan Yarema in "Haydamaks" is a vivid embodiment of a reborn from a hireling, a Jewish

2 Античная литература: Учеб. для студентов пед. ин-тов. А.Ф. Лосев, Г.А. Сонкина, А.А. Тахо-Годи и др. Под ред. А.А.Тахо-Годи. 4-е изд., дораб. М. Просвещение. 1986. 464 с.

3 Літературознавча енциклопедія: У двох томах. Т. 1. Авт.-уклад. Ю.І.Ковалів. К. ВЦ “Академія”. 2007. С. 294.

${ }^{4}$ Генералюк Л. Універсалізм Шевченка: взаємодія літератури і мистецтва. Київ. Наукова думка. 2008. 544 с.

${ }^{5}$ Іванишин П. Вульгарний “неоміфологізм”: від інтерпретації до фальсифікації Т.Шевченка. Дрогобич. ВФ “Відродження”. 2001. 174 с.; Іванишин П.В. Національний спосіб розуміння в поезії Т. Шевченка, Є. Маланюка, Л. Костенко: монографія. К. Академвидав. 2008. 392 с. 
person of a Cossack person, (the evidence of which is the Haydamak's nickname and his symbolic adoption by Zaliznyak), but ordinary, average type. And this is quite natural, because the essential (existential) Cossack is the one who lives as a Cossack, leading the Cossack way of being. While Gonta is an embodiment of a different type of Cossack presence, a person is definitely extraordinary. And the evidence of this is his not so real life (although there is a lot of exceptional and heroic in it, if at least to recall the knightly, stoic behavior of this leader during inhumane torture), just like the artistic living, which is depicted in the poem.

It seems that for the poet in his sad time (mid-nineteenth century) of total dominance of the type of imperial, colonized, dissolved in the Russian world person - "slaves with a cockade on the forehead", "lackeys in golden decoration" ("In Judah, in the days of them ...") - an important artistic task was to depict a real elite of the people, prototypes for which he finds in the heroic Cossack past (Ivan Pidkova) or creates in his imagination (Gamalia) in folklore and romantic tradition. That is looking for in the blessed and often deliberately idealized time - "as we were Cossacks" ("To the Poles"). It is about the image of the leader-man, the "knight", the upper level of the social hierarchical ladder, the spiritual nobleman, subsequently so thoroughly comprehended in the philosophy of Dmytro Dontsov ${ }^{6}$ and the literary work of other visnykivtsi.

By the way, the deep allegorical image of the organic leader (as the "shepherd"), which goes beyond the strictly religious sense, is observed in the New Testament. Christ, in one of his parables, takes out an antinomic pair, opposing the "good shepherd" to the pseudo-elite (heteronomous) "hireling": "I am a good shepherd. A good shepherd will put his life behind the sheep. A hireling is not a shepherd to whom the sheep belong - sees the wolf coming in and leaves the sheep and runs away. And the wolf grabs them and shakes. Because he is a hireling and does not care about the sheep" (Jn 10: 11-15) ${ }^{7}$. It is typical that such a parabolic interpretation of the spiritual type of the leader (and, accordingly, the false leader) is echoed with the existential identification of a person just as a shepherd or shepherd

\footnotetext{
${ }^{6}$ Донцов Д. Дух нашої давнини. Дрогобич. ВФ “Відродження”. 1991. 341 с.

${ }^{7}$ Святе Письмо Старого і Нового Завіту. Рим. б.в. 1988. 1407 с.
} 
of being in the hermeneutics of Martin Heidegger. The German philosopher perceives the shepherd nature through the mode (existential) of care: "People are still what they are worried about" leader, from here, is when he really cares not about private, family or clan, but nationwide things and affairs.

In the poetry of $\mathrm{T}$. Shevchenko in such christological-nationalistic spirit (from here the criteria and frequent criticism of false leaders by the poet, for example, in the "Epistle") it is depicted many heroes-leaders. However, as it seems suitable to remark, the image of Ivan Honta, which was taken out in "Haydamaks", still appears as the key ideal image of the Ukrainian elite ("knightly", according to T. Shevchenko) here-being (the leader of the people). It is with the help of this throughout romantic character the author interprets to the recipient who must be a true national leader.

His final development the image of Gonta as an image of the leader (shepherd) of the people gets in the culminating part of the poem "Gonta in Uman". In contrast to the historical Gonta, who had four daughters and one son and who did not hurt them in any way ${ }^{9}$, Shevchenko's character in the spirit of artistic truth (according to the realities of the figurative world, to the content and meaning of the poem) makes an impressive action on the strength of the spirit - he executed two of his small Catholic sons during the battle in Uman, directly provoked to do this by the words of their Jesuit instructor: "Look, Gonta, look! These youngsters are your sons! They're Catholics: since you kill all, Can you leave them alone? Why are you waiting? Kill them now, Before your sons are grown, For if you don't, when they grow up They'll find you and they'll kill...",".

Historical Gonta personally saved many familiar umantsi from Haydamak's revenge, demonstrating a typical deep humanity for the

\footnotetext{
${ }^{8}$ Хайдеггер М. Бытие и время. Пер. с нем. В.В.Бибихина. Харьков. “Фолио”. 2003. C. 362 .

9 Зінчук С. Славні хлопці гайдамаки. Запорожці: До історії козацьк. культури. Упоряди. тексту, передм. І. Кравченка. Упорядк. іл. матеріалу Ю. Іванченка. К. Мистецтво. 1993. С. 255.

10 Шевченко Т.Г. Повне зібрання творів: У 12 т. Редкол. М.Г. Жулинський (голова) та ін. К. Наук. думка. 2001. Т. 1. Поезія 1837-1847. Перед. слово І.М. Дзюби, М.Г. Жулинського. С. 181.
} 
temper of an ethnic Ukrainian. His literary embodiment also shows humanity, but of a different type, and in another way. For this significant dramatic action, the murder of children, is suitable not ordinary, but only a great man, in another classical terminology, the hero (that is, in the ideas of the ancients - the demigod, the holy, divine, hero, the ideal person, etc.). And that exactly a person, and not a demonized, immoral cruel person, proves yet another psychologically tense megaimage (scene) of the part the secret funeral of the killed sons by Gonta ("... so that the Cossack small body / Dogs did not eat”), where a huge parental love pours out bloody tears, self-punishment, but not repentance: "My children! Open up your eyes, Look at Ukraine, my boys: For her, my sons, you gave your lives And I, too, am destroyed"

Only a great man, a true leader of the people, has the wisdom to subordinate the smaller, privately-owned love (parental) to a larger, allencompassing, overpersonal (sacrificial love for the Motherland). Here, love for children is like a continuation of the Fichte's love of man to "himself", which, in order the people to live, should not predominate over "love for the Motherland"12. Only a great man, a true Christian, a "good shepherd" has the nobility to realize that the "great sin" (according to Weber's "persuasion ethics") of murdering children is still less a sin than a shepherd sin (according to the ethics of responsibility) of national treason the murder of the faith of his spiritual children-charges (especially during the time of the nation-wide war for freedom, as Shevchenko rethinks in his poem the historical and, in some aspects, destructive rebellion of the coliyi in 1768). Because in this case it is, in fact, about the murder of a coexistential mode of trust between the leader and his subordinates, his new family, and the "children" is a constant appeal of atamans to simple haydamaks. Only a great man, a leader of the people, a true Cossackknight, has the courage to regulate his actions with a position of good for the community and, if necessary, can donate the family happiness for the

11 Шевченко Т.Г. Повне зібрання творів: У 12 т. Редкол. М.Г. Жулинський (голова) та ін. К. Наук. думка. 2001. Т. 1. Поезія 1837-1847. Перед. слово І.М. Дзюби, М.Г. Жулинського. С. 185-186.

12 Фіхте Й.Г. Із праці “Промови до німецької нації”. Мислителі німецького Романтизму. Упор. Леонід Рудницький та Олег Фешовець. Івано-Франківськ. Лілея-НВ. 2003. C. 235; C. 133. 
sake of everyone happiness. The presence of a leader is structured not only by parental care (which is normal for an ordinary national person of a family type in normal, peaceful time of the world "cherry garden near the house"), but nationwide care - national imperative embodied in the form of an "oath" (dominant in the boundary, according to K. Yaspers, dramatized war time of the world of "sable" or "sacred knife"):

The Cossacks stood

Assembled in the square.

"My sons are Catholics.... I vowed

No Catholic to spare.

Esteemed assembly!... That there should

Be no doubt anywhere,

No talk that I don't keep my word,

Or that I spare my own..."

“...Such woe, my sons, today is mine

As cannot be conceived!

My children, kiss me, for not I

Am killing you today -

It is my oath! ", 13 .

\section{Gonta's heroism in the comparative aspect}

Comparisons, to which the Shevchenko's scholars properly paid attention (although often episodically) and which are concerning to the action of the biblical patriarch Abraham, who was ready to sacrifice his innocent son Isaac to God (Genesis 22: 1-13), the sacrifice of the daughter Iphigenia to Artemis by the Achaean king Agamemnon in the "Iliad" by Homer, or, again, kid murder, but deserved, of the renegade son Andrew by Taras Bulba depicted in M. Gogol's work, can be a good context for a clearer understanding of Gonta's action and, from here, the greatness of his leading nature (Gonta emerges as a potential political leader of the restored Cossack state). These comparative parallels

13 Шевченко Т.Г. Повне зібрання творів: У 12 т. Редкол. М.Г. Жулинський (голова) та ін. К. Наук. думка. 2001. Т. 1. Поезія 1837-1847. Перед. слово І.М. Дзюби, М.Г. Жулинського. С. 182. 
explain the action of the Haydamak's ataman in many aspects, however, besides this, no less important are such historical examples (the primary sources of many literary stories in different European peoples), on one of which I. Franko hints (obviously developing the opinion of P. Kulish), though not perceiving the action of Haydamak's ataman, "Shevchenko makes Ukrainian Brutus from Gonta" 14 . So, let's appeal to the ancient historians for explanation, remembering that T. Shevchenko holds an active creative dialogue with different traditions (Christian, folklore, historical, literary, etc.), and also (as it was retraced in the writings of O. Biletskiy or Yu. Boyko) with ancient tradition (both in their paintings and in literary works).

Killing yourself or your relatives in the name of an over-personal goal, often for the sake of preserving the existence of the native people (the existence of the nation, as we would have said now), is quite common in the ancient history of various cultures, although perhaps the history of the Romans as semi-artistic story about the formation of a powerful Roman state offers us the most documented evidences. What is worthy the murder of his sister by Horace at least described by Titus Livius. This hero, triumphantly returning from a difficult battle and carrying an armor got in the fight of the twins he killed - Albanians Kurnatsiyi, noticed how his sister cries at the gates of Rome for one of them - her groom. Indignant by the fact that the girl is not crying for two dead brothers (killed by Kurnatsiyi, the fight was - three to three), the brother pierces her with a sword, saying, among other things, the following: “... you forgot about the brothers - about the dead and the living one - forgot about the motherland. Let every roman woman, who will mourn for the enemy, die like this!". Horace was judged by the people, but at the request of his father and under the impression of the previous feat the young man was pardoned ${ }^{15}$.

The action of Horace, though carried out for the sake of the people (the Romans should not mourn the enemy of their motherland), is rather,

${ }^{14}$ Франко І. Нарис історії українсько-руської літератури до 1890 р. Франко І. Зібр. творів: У 50 т. К. Наукова думка. 1984. Т. 41. С. 277-278.

15 Ливий Тит. История Рима от основания Города: В 3 т. Т. 1. Кн. І-Х. Тит Ливий. Сост. коммент. В.М. Смирин, Г.П. Чистяков, Ф.А. Михайловский. М. «Ладомир». 2002. C. 36-38. 
unreasonable, impulsive, instead, the murder of his sons by the first Roman consul, Lucius Junius Brutus (who was called "the father of freedom") was a weighted decision and more like a strict rank of Gonta. Soon after the Romans, draw out the family of the degenerated (and therefore tyrannical) kings Tarquiniyi under the leadership of Brutus, the ancient authors say, the freedom of the republic almost ruined the plot of some young and noble Romans, who entered into relations with the king Tarquiniy The Proud. The plot was revealed, and two sons of Brutus - Titus and Tiberius (the first typical parallel with the artistic model of kid murder in "Haydamaks") were between the rebels.

The following description of the events in the sources is slightly different. According to Titus Livius, the consul Brutus along with his friend by the consulate Publius Valery convicts the rebels (the betrayers not only of "liberated motherland" and "father-liberator", but "all that was in Rome of God and man") to a public execution (according to a custom, the lictors flog convicted near the post and decapitated with an ax). During the execution Brutus sits on his power seat, his face and his vision "show a parental feeling, even realizing people's violence" 16 . We see similarity in the Gonta's words during the execution of his sons, speaking in Shevchenko's words, the "breaking" of the "living heart" ("Cold Ravine"), we hear a great, although restrained in front of face of the congeners, pain of "parental feelings" (especially bright in that - "... Kiss me, children, / Because I do not kill...”), which fully manifests itself during a lonely funeral.

Plutarch's description is even stricter. Brutus immediately after questioning the sons on the forum orders them to execute. At the same time, he does not take his eyes, without sympathy, watches at the punishment of his children with a strict look. Sending the rest of the rebels to the court of his comrade on the post, Brutus goes away. Ancient Greek historian points out that the consul's action "steps out beyond the human nature" (F. Nietzsche maybe would call it as the action of a superman), but warns the reader of the conviction: "More fairly ... that our reflection about

16 Ливий Тит. История Рима от основания Города: В 3 т. Т 1. Кн. І-Х. Тит Ливий. Сост. коммент. В.М.Смирин, Г.П.Чистяков, Ф.А.Михайловский. М. «Ладомир». 2002. C. $77-80$. 
this man goes after his glory, and our own weakness should not be the cause of distrust of his valor. In any case, the Romans believe that not so much work cost Romulus to found a city, but Brutus - to found and strengthen a democratic way of government" ${ }^{\prime 17}$. T. Shevchenko models similar "high valor" in the character of Gonta and, creating the ideal model of a statesman - the leader of the people, which had a fundamental nationcreative in the crushing conditions of Russian occupation and colonization of Ukraine.

However, at least one essential detail of the rank of Brutus is still different from that one of Gonta: the sons of the consul were still guilty for the betrayal of the Romans, and the fault of the young Ukrainians is more formal - they are "Catholics" (converted by the mother, and therefore, they belong, according to the tradition of that time, to another, Polish, national identity), and only because of this fall under the sacred Haydamak's oath. True, the sons of Gonta are only potential, possible (and then in the future), but not efficient (actual) enemies of the people or people's affair, and in this case, the rank of the Haydamak's leader in the poem predominates over the grandeur of spirit, dramatism, tensity of will power, a similar action of the Roman leader. In the outlined moment, the courageous Gonta's action manifests through two more comparative parallels.

The first one concerns to Brutus's congener in the consulate Publius Valery (in Rome nicknamed Publikola - "the friend of the people"), who, according to Plutarch's evidence, destroyed one of his magnificent, luxurious houses in one night, precisely in order to "have no talk", speaking in Shevchenko's words, so that the Romans could not even see the symbol of the tyranny of exiled Tarquinia in such a building - the ruined royal palace ${ }^{18}$. However, the property is not children. Here the similarity is less profound, narrowed typological. Titus Livius gives us another parallel on the example of the Roman consul, Titus Manliy, who swore to give life to the Roman people (compare with the "oath" of Gonta) and ordered to punish his son on the throat, for the fact that during a very exhausting and dangerous war with

17 Плутарх. Сравнительные жизнеописания в 3-х томах, т. III. СПб. Кристалл. 2001. C. 184-188.

${ }^{18}$ Плутарх. Сравнительные жизнеописания в 3-х томах, т. III. СПб. Кристалл. 2001. С. 191. 
Latins, broke the order and entered the battle with the enemy. And although the son won the enemy rider in the fight, the consul, not forgetting that he was a father (“... you are dear to me, as my natural son ..."), nevertheless he punishes him for a bad example (“...blew up obedience in the army, on which the Roman state still remained..."), which could cause to anarchy, otamanshchyna (such sadly famous in later Roman and Ukrainian histories), and hence to the death of the Roman people and the state. Choosing between the death of his son, which should "strengthen the sacred power of the consuls in the war" and pardon, which "will forever blow up" the faith in this power, Manliy, like Gonta, chooses the first ${ }^{19}$.

Parallels with the great leaders (first of all politicians) of the Roman people, the classical incarnations of the Roman man (presence) - Horace, Brutus, Valerius and Manliy - help us to comprehend the greatness of the artistic character of the Ukrainian leader - Ivan Gonta. In all cases, we probably have to deal (here it is worthy to generalize the opinion of the Russian historian G. Knabe) "not with barbarian cruelty, and all with the same faithfulness to freedom, before which everything retreats" 20 . True, it is very difficult to comprehend the people who are blocked by certain universalist - imperial or cosmopolitan - stereotypes and a way of thinking, with which, incidentally, T. Shevchenko's hero wittily argues in the introduction to "Haydamaks". "It is said: If we are slaves ourselves, then for us there can be no heroes. We do not recognize the hero ..."21 wrote a philosopher Thomas Carlyle from a similar occasion.

T. Shevchenko, as a special aristocrat of the spirit, comprehended the heroic phenomenon very deeply. It is no by chance that in his poetry he introduces an original (because it is not about religious or mythological "adoration", 22 but, obviously, the confirming of the essential artistic and existential mode of respect as a kind of care) cult of Gonta as a hero. That

19 Ливий Тит. История Рима от основания Города: В 3 т. Т 1. Кн. І-Х. Тит Ливий. Сост. коммент. В.М. Смирин, Г.П. Чистяков, Ф.А. Михайловский. М. «Ладомир». 2002. C. $453-454$.

${ }^{20}$ Кнабе Г.С. Рим Тита Ливия - образ, миф, история. Ливий Тит. История Рима от основания Города: В 3 т. Т. 3. Кн. XXXIV-XLV. Тит Ливий; Сост. коммент. В.М. Смирин, Г.П. Чистяков, Ф.А. Михайловский. М. «Ладомир». 2002. С. 763.

${ }^{21}$ Антология мировой философии. В 4-х т. М. Мысль. 1971. Т. 3. С. 657.

22 Словник іншомовних слів. Уклад.: С.М. Морозов, Л.М. Шкарапута. К. Наук. думка. 2000. С. 309. 
is an example for imitation as almost inaccessible to an ordinary person, as the embodiment of "Cossack's glory", finally, as a hero (the historycreative "great man") in a philosophical and national sense ${ }^{23}$. Such Shevchenko's interpretation resembles the interpretation of the hero in the ancient Greeks as "an outstanding ancestor - the leader, the legendary founder of the tribes and peoples, the founder of cities" etc. ${ }^{24}$, and in the etymologically Christological sense as the saint ("righteous martyr"), which is being actualized in the poem too. At the same time, the lyrical hero reproaches the "grandchildren" (modern yarema-persons) who are indifferent to the Haydamak's affair, who do not even know where are the graves of Honta and Zaliznyak. That is, they do not know very important existing ones (and not only for the lyrical hero) in the nation-creative sense, do not know their spiritual ancestors, do not know the basics and sources of their national being: "Hard! Hard! Executioner rules, / And they will not be remembered ${ }^{, 25}$.

Naturally, therefore, the image of Gonta, and even more the Cossack character embodied in this form, is taken out as one of the leading ideals of the Ukrainian person (both for the ordinary and for the leading types). He is taken out as one of the models of national here-being in a number of T. Shevchenko's works until the end of his creative work. We see such an author's interpretation in the message "To Gogol" (1844): "No cannon roar now in Ukraine / With voice of Liberty; / Nor will the father slay his son, / His own dear child, with pain, / For honour, glory, brotherhood, / The freedom of Ukraine. / He'll rather rear him up to sell / To Moscow's slaughterhouse..."26. And in the mystery "The Great Cellar" (1845) (the image of the first John, all three crows are frightened by him): "One

${ }^{23}$ Карлейль Т. Герои, культ героев и героическое в истории. Психология толпы: социальные и политические механизмы воздействия на массы. М. Изд-во Эксмо. Спб. Terra Fantastica. 2003. C. 469-717.

${ }^{24}$ Плутарх. Сравнительные жизнеописания в 3-х томах, т. III. СПб. Кристалл. 2001. C. 620.

${ }^{25}$ Шевченко Т.Г. Повне зібрання творів: У 12 т. Редкол. М.Г. Жулинський (голова) та ін. К. Наук. думка. 2001. Т. 1. Поезія 1837-1847. Перед. слово І.М. Дзюби, М.Г. Жулинського. С. 158.

26 Шевченко Т.Г. Повне зібрання творів: У 12 т. Редкол. М.Г. Жулинський (голова) та ін. К. Наук. думка. 2001. Т. 1. Поезія 1837-1847. Перед. слово І.М. Дзюби, М.Г. Жулинського. С. 284. 
will be like that Gonta, / Torture the executioners (...) / ... when that Gonta will grow, / All our will be lost! / Everything will destroy / And he will not leave the brother! / And will dismiss the truth and will / Throughout Ukraine!" "27. And in the images of Haydamak's and their leaders in the "Seamstress"28 (1848). And in this real man - "one Cossack / of a million swineherds, / Who declared the whole kingdom - / flooded Satrap in the muzzle,29 - from the "Holy fool" (1857). And in many other works, where this Cossack character is expressed obviously ("Blind man" (1845) or "Sometimes, in slavery I will remember ..." (1857)) or hidden, often in the image of the lyrical hero ("Neophytes", "Dream", "Caucasus", "I'm not sick, nothing...", "If you had to ...", "If you were, drunk Bogdan ...", "In Judah, in the days of them...", "Hosea, Chapter IV", "Somehow going at night ...", "Imitation to 11 psalm", etc.).

However, the most clearly Shevchenko expresses his interpretation of Gonta with the lyrical hero's lips in "Cold Ravine" (1845), answering all the past, contemporary, and future Ukrainophobes ("new executioners", "fierce Neros", "tsaryks", "liudomors", "unsatisfied robbers") and their alienated from the life-giving national tradition assistants ("fools", "sheep's natures”, “lazy lazybones”):

Forsooth yours is

Indeed a sheeplike nature!

The fool offers his neck, not knowing

What for it is wanted,

And, what is more, the idle loafer

Scorns and sneers at Gonta!

The Haydamaky were no warriors,

Thieves they were, and robbers,

A blot upon our history!

27 Шевченко Т.Г. Повне зібрання творів: У 12 т. Редкол. М.Г. Жулинський (голова) та ін. К. Наук. думка. 2001. Т. 1. Поезія 1837-1847. Перед. слово І.М. Дзюби, М.Г. Жулинського. С. 322.

${ }_{28}$ Шевченко Т.Г. Повне зібрання творів: У 12 т. Редкол. М.Г. Жулинський (голова) та ін. К. Наук. думка. 2001. Т. 2. Поезія 1847-1861. С. 133-134.

29 Шевченко Т.Г. Повне зібрання творів: У 12 т. Редкол. М.Г. Жулинський (голова) та ін. К. Наук. думка. 2001. Т. 2. Поезія 1847-1861. С. 258. 
Thou liest, people-starver:

For freedom and the holy truth

A robber does not rise up,

Nor does he set free a people

Who, dark, unlightened,

Are bound into your chains, does not

Slay with his own hand

An evil son, nor break his living

Heart for his native land! ${ }^{30}$.

\section{CONCLUSIONS}

Thus, in the image of Ivan Gonta, T. Shevchenko forever prints the Ukrainian archetypal ideal of the Cossack knight's presence for the entire national culture of the New Age, a high, heroic example of herebeing a great man, the leader of the nation. Therefore, probably, those researchers, who, like D. Dontsov, are not very wrong in conclusions from the poetry of Kobzar that only the leading class, armed with spiritual knights' worth of wisdom, nobility and courage, "a race of strong spirits of giants" (Gonta or Mazepa) is capable to take Ukraine out of colonial hell "from the darkness, from stench, from slavery"31. In this, as it seems possible to notice, it is one of the essential, ontological and existential aspects of what Yu.Boyko defines as "the life-creative force of nationalism"32.

We are well aware that the mentioned above comparative parallels and accompanying national-existential (nationalistic) hermeneutic reflections are far from exhausting the problem. However, we hope that they can be developed in other studios in plan of complex, versatile interpretation of the whole poem "Haydamaks" as one of the key works to understand the creative work of Taras Shevchenko.

30 Шевченко Т.Г. Повне зібрання творів: У 12 т. Редкол. М.Г. Жулинський (голова) та ін. К. Наук. думка. 2001. Т. 1. Поезія 1837-1847. Перед. слово І.М. Дзюби, М.Г. Жулинського. С. 356.

31 Донцов Д. Незримі скрижалі Кобзаря (Містика лицарства запорозького). Торонто. Гомін України. 1961. С. 25; С. 81.

32 Бойко Ю. Творчість Тараса Шевченка на тлі західноєвропейської літератури. Бойко Ю. Вибране. У 3 т. Мюнхен, 1971. Т. 1. С. 295. 


\section{SUMMARY}

In the article in hermeneutic and comparative plans, it is considered the rank of centurion Ivan Gonta in the poem by T. Shevchenko "Haydamaks". The researcher focuses on comparative parallels with antique (first of all ancient Roman) heroes, which allow us to comprehend the authentic, immanent meaning of the most controversial scene in the poem "Haydamaks" - the murder of his own young children by Ivan Gonta. In general, Gonta is an embodiment of another, in comparison with the usual, type of Cossack presence, a person clearly extraordinary. And there is evidence of this, not so real his life (although there are many exceptional and heroic, if at least turn to memories, stoic behavior of this leader during inhuman torture), just like that artistic residence, which is described in the poem. That's why, the author emphasizes that the poet, in the form of the Haydamak's leader, models the Ukrainian heroic ideal of the national leader. That is, in the image of Ivan Gonta T. Shevchenko forever marks for the entire national culture of the New Age the Ukrainian archetypal ideal of the Cossack knight's presence, the high, heroic example of here-being a great man - the leader of the nation. For the context the images of ancient heroes - Horace, Brutus, Valery, Manliy, depicted in the works of Titus Livius and Plutarch, are enlisted. These mentioned comparative parallels and accompanying national-existential (nationalistic) hermeneutic reflections are far from exhausting the problem. However, the researcher hopes that they can be developed in other studios in plan of complex, versatile interpretation of the whole poem "Haydamaks" as one of the key works to understand the creative work of Taras Shevchenko.

\section{REFERENCES}

1. Античная литература: Учеб. для студентов пед. ин-тов. А.Ф. Лосев, Г.А. Сонкина, А.А. Тахо-Годи и др. Под ред. А.А. ТахоГоди. 4-е изд., дораб. М. Просвещение. 1986. 464 с.

2. Антология мировой философии. В 4-х т. М. Мысль. 1971. T. $3.760 \mathrm{c.}$

3. Барабаш Ю. “Коли забуду тебе, Єрусалиме...”. Гоголь $i$ Шевченко. Порівняльно-типологічні студії. Харків. Акта. 2001. 374 с. 
4. Бойко Ю. Творчість Тараса Шевченка на тлі західноєвропейської літератури. Бойко Ю. Вибране. У $3 \mathrm{~m}$. Мюнхен, 1971. T. 1. С. 261-312.

5. Генералюк Л. Універсалізм Шевченка: взаємодія літератури і мистецтва. Київ. Наукова думка. 2008. 544 с.

6. Донцов Д. Дух нашої давнини. Дрогобич. ВФ “Відродження”. $1991.341 \mathrm{c}$.

7. Донцов Д. Незримі скрижалі Кобзаря (Містика лицарства запорозького). Торонто. Гомін України. 1961. 231 с.

8. Зінчук С. Славні хлопці гайдамаки. Запорожиі: До історії

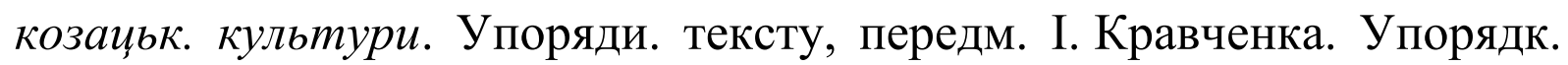
іл. матеріалу Ю.Іванченка. К. Мистецтво. 1993. С. 252-280.

9. Іванишин П. Вульгарний “неоміфологізм”: від інтерпретації до фальсифікації Т. Шевченка. Дрогобич. ВФ “Відродження”. 2001. $174 \mathrm{c}$.

10. Іванишин П.В. Національний спосіб розуміння в поезії Т. Шевченка, С. Маланюка, Л. Костенко: монографія. К. Академвидав. 2008. 392 с.

11. Карлейль Т. Герои, культ героев и героическое в истории. Психология толпы: сочииальные и политические механизмы воздействия на массы. М. Изд-во Эксмо. Спб. Terra Fantastica. 2003. C. 469-717.

12. Кнабе Г.С. Рим Тита Ливия - образ, миф, история. Ливий Тит. История Рима от основания Города: В 3 m. T. 3. Кн. ХХXIV-XLV. Тит Ливий; Сост. коммент. В.М. Смирин, Г.П. Чистяков, Ф.А. Михайловский. М. “Ладомир”. 2002. С. 647-709.

13. Ливий Тит. История Рима от основания Города: В 3 т. Т 1. Кн. І-Х. Тит Ливий. Сост. коммент. В.М. Смирин, Г.П. Чистяков, Ф.А. Михайловский. М. “Ладомир”. 2002. 702 с.

14. Літературознавча енциклопедія: $\mathrm{У}$ двох томах. Т. 1. Авт.-уклад. Ю.І. Ковалів. К. ВЦ “Академія”. 2007. 608 с.

15. Плутарх. Сравнительные жизнеописания в 3-х томах, т. III. СПб. Кристалл. 2001. 772 с.

16. Святе Письмо Старого і Нового Завіту. Рим. б.в. 1988. 1407 с. 
17. Словник іншомовних слів. Уклад.: С.М. Морозов, Л.М. Шкарапута. К. Наук. думка. 2000. С. 309.

18. Фіхте Й.Г. Із праці “Промови до німецької нації”. Мислителі німеиького Романтизму. Упор. Леонід Рудницький та Олег Фешовець. Івано-Франківськ. Лілея-НВ. 2003. С. 110-134.

19. Франко I. Нарис історії українсько-руської літератури до 1890 р. Франко І. Зібр. творів: У 50 m. К. Наукова думка. 1984. Т. 41. C. 194-471.

20. Хайдеггер М. Бытие и время. Пер. с нем. В.В. Бибихина. Харьков. “Фолио”. 2003. 503 с.

21.Шевченко Т.Г. Повне зібрання творів: У 12 т. Редкол. М.Г. Жулинський (голова) та ін. К. Наук. думка. 2001. Т. 1. Поезія 1837-1847. Перед. слово І.М. Дзюби, М.Г. Жулинського. 784 с.

22. Шевченко Т.Г. Повне зібрання творів: У 12 т. Редкол. М.Г. Жулинський (голова) та ін. К. Наук. думка. 2001. Т. 2. Поезія 1847-1861. 784 c.

\section{Information about the author:} Ivanyshyn P. V.,

Doctor of Philology, Professor, Head of the Department of Ukrainian Literature and Theory of Literature, Drohobych State Pedagogical University named after Ivan Franko 24, Shevchenko str., Drohobych, 82100, Ukraine 